Keywords: SCIX, DWPF,

Titanium, Glass, Durability

Retention: Permanent

\title{
Summary Report on Potential Impacts of Small Column Ion Exchange on DWPF Glass Formulation
}

\author{
K. M. Fox \\ T. B. Edwards \\ F. C. Johnson
}

April 2011

Savannah River National Laboratory Savannah River Nuclear Solutions, LLC Aiken, SC 29808

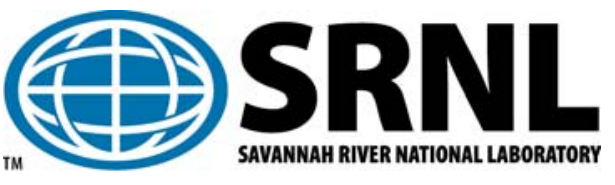


SRNL-STI-2011-00198

Revision 0

\section{DISCLAIMER}

This work was prepared under an agreement with and funded by the U.S. Government. Neither the U.S. Government or its employees, nor any of its contractors, subcontractors or their employees, makes any express or implied:

1. warranty or assumes any legal liability for the accuracy, completeness, or for the use or results of such use of any information, product, or process disclosed; or

2. representation that such use or results of such use would not infringe privately owned rights; or

3. endorsement or recommendation of any specifically identified commercial product, process, or service.

Any views and opinions of authors expressed in this work do not necessarily state or reflect those of the United States Government, or its contractors, or subcontractors.

\section{Printed in the United States of America \\ Prepared for \\ U.S. Department of Energy}




\section{REVIEWS AND APPROVALS}

AUTHORS:

K. M. Fox, Process Technology Programs

Date

T. B. Edwards, Applied Computational Engineering \& Statistics

Date

F. C. Johnson, Process Technology Programs

Date

TECHNICAL REVIEW:

D. K. Peeler, Process Technology Programs

Date

APPROVAL:

C. C. Herman, Manager

Date

Process Technology Programs

F. M. Pennebaker, Manager

Date

SRNL SCIX Program

S. L. Marra, Manager

Date

Environmental \& Chemical Process Technology Research Programs

J. E. Occhipinti, Manager

Date

Waste Solidification Engineering

T. H. Huff, Manager

Date

SCIX Engineering 


\section{ACKNOWLEDGEMENTS}

The authors would like to thank Irene Reamer, Phyllis Workman, Pat Simmons, Whitney Riley, David Best, Debbie Marsh, Myra Pettis, Kevin Kalbaugh, Bridget Miller, David Missimer, Beverly Wall, Mark Jones, Damon Click, and Boyd Wiedenman for their assistance with the fabrication and characterization of the glasses in this study. The authors would also like to thank Dr. David Peeler for his suggestions and helpful discussions. 


\section{EXECUTIVE SUMMARY}

This report summarizes a large amount of experimental work completed to identify the potential impacts of material from Small Column Ion Exchange (SCIX) on glass formulation at the Defense Waste Processing Facility (DWPF). The results show no significant issues with the predicted values of chemical durability and viscosity using the current Product Composition Control System (PCCS) models when the SCIX components are added to projected DWPF glass compositions. No modifications to the viscosity and durability models appear to be necessary at this time in order to incorporate the SCIX streams at DWPF. It is recommended that the Savannah River National Laboratory (SRNL) continue to verify the durability and viscosity models as the projected compositions for DWPF processing evolve. It is also recommended that the data generated thus far be reviewed and a determination be made as to how best to extend the validation ranges of the durability and viscosity models.

The liquidus temperatures for the experimental glasses are also reported and discussed in this report. The results show that the measured or estimated (based on measured data) liquidus temperature values for the glasses with SCIX components added are consistently higher than those predicted by the current model. Therefore, the PCCS liquidus temperature model will need to be modified in order to incorporate the SCIX streams at DWPF. It is recommended that SRNL carry out full measurements of the liquidus temperatures for those KT-series glasses where estimates have been made. These data should then be used to support an evaluation of whether a refitting of the liquidus temperature model coefficients will be sufficient to correctly predict the liquidus temperature of glasses containing the SCIX components (particularly higher $\mathrm{TiO}_{2}$ concentrations), or whether additional modifications to the model are required.

While there are prediction issues with the current liquidus temperature model, they are not at this time expected to hamper the incorporation of SCIX streams at DWPF. The estimated liquidus temperatures, while higher than the model predicted values, remain below the current DWPF limit of $1050{ }^{\circ} \mathrm{C}$ for most of the study glasses. Note that the properties and performance of the glasses in this study are highly dependent on glass composition. Therefore, should significant changes be made to the projected compositions or processing rates for SCIX or DWPF, many of the assessments and experiments may have to be revisited. 


\section{TABLE OF CONTENTS}

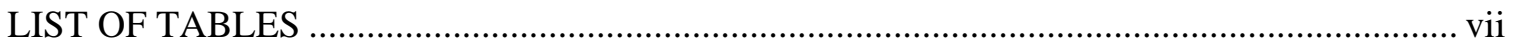

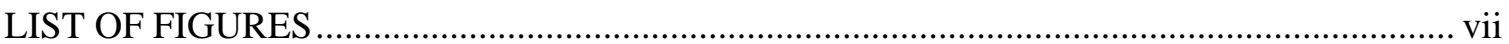

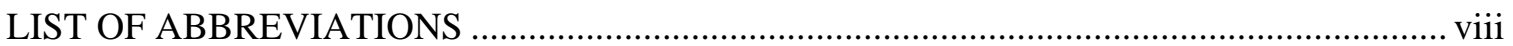

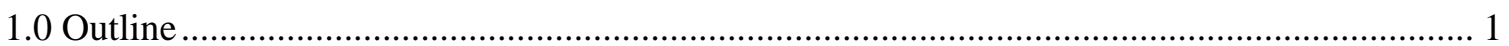

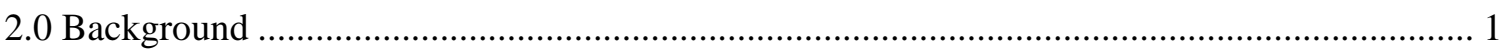

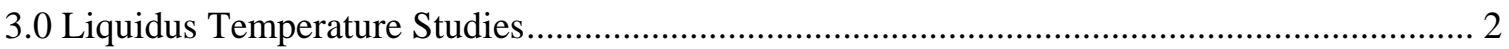

4.0 Summary of Studies of Potential Impacts of SCIX on DWPF Glass Formulation ................... 9

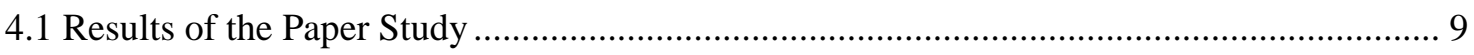

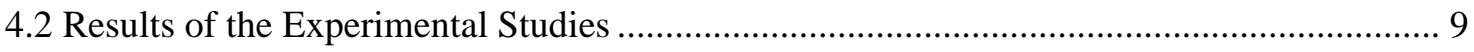

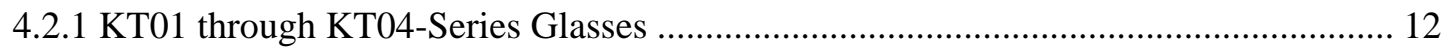

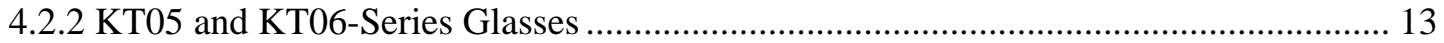

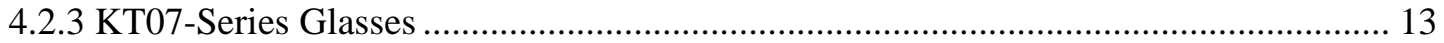

4.2.4 KT08 through KT10-Series Glasses: .............................................................................. 14

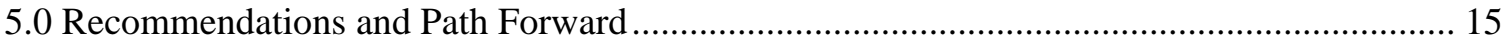

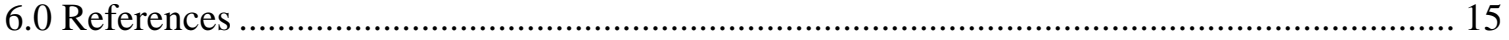




\section{LIST OF TABLES}

Table 4-1. Summary of Studies for SCIX Impacts on DWPF Glass Formulation. 10

\section{LIST OF FIGURES}

Figure 3-1. Liquidus Temperature Measurements for the KT01-Series Glasses. .......................... 3

Figure 3-2. Liquidus Temperature Estimates for the KT03-Series Glasses. .................................. 4

Figure 3-3. Liquidus Temperature Estimates for the KT04-Series Glasses. .................................. 5

Figure 3-4. Liquidus Temperature Estimates for the KT06-Series Glasses. ................................. 6

Figure 3-5. Liquidus Temperature Estimates for the KT07-Series Glasses. ................................ 7

Figure 3-6. Liquidus Temperature Estimates for the KT10-Series Glasses. ................................. 8 


\section{LIST OF ABBREVIATIONS}

$\begin{array}{ll}\text { CCC } & \text { Canister Centerline Cooled } \\ \text { CST } & \text { Crystalline Silicotitanate } \\ \text { DWPF } & \text { Defense Waste Processing Facility } \\ \text { EA } & \text { Environmental Assessment } \\ \text { HLW } & \text { High Level Waste } \\ \text { ICP-AES } & \text { Inductively Coupled Plasma - Atomic Emission Spectroscopy } \\ \text { MAR } & \text { Measurement Acceptability Region } \\ \text { M\&TE } & \text { Measurement and Test Equipment } \\ \text { MST } & \text { Mono Sodium Titanate } \\ \text { PCCS } & \text { Product Composition Control System } \\ \text { PCT } & \text { Product Consistency Test } \\ \text { RMF } & \text { Rotary Micro Filter } \\ \text { SCIX } & \text { Small Column Ion Exchange } \\ \text { SRNL } & \text { Savannah River National Laboratory } \\ \text { SRS } & \text { Savannah River Site } \\ \text { SWPF } & \text { Salt Waste Processing Facility } \\ \text { TL } & \text { Liquidus Temperature } \\ \text { TTT } & \text { Time-Temperature-Transformation } \\ \text { XRD } & \text { X-ray Diffraction }\end{array}$




\subsection{Outline}

This report is intended to summarize a large amount of experimental work completed in support of the Small Column Ion Exchange (SCIX) Program at the Savannah River Site (SRS). The work was performed to identify the potential impacts of material from SCIX on glass formulation at the Defense Waste Processing Facility (DWPF). This summary report is divided into sections, as follows: Section 2.0 provides brief background information on the SCIX program and its potential impacts to DWPF glass formulation. Section 3.0 details the liquidus temperature experiments that have been performed in support of this study. These data require a significant amount of time to collect; therefore, they could not be included in the previous technical reports. Section 4.0 provides a summary and review of all of the studies completed to date, including paper studies using model predicted properties and experimental glasses fabricated and characterized in the laboratory. Section 5.0 presents an overall summary of the study and provides recommendations for continued work.

All of the work discussed in this report was initiated by a DWPF Technical Task Request ${ }^{1}$ and was performed following a Task Technical and Quality Assurance Plan. ${ }^{2}$

\subsection{Background}

The SRS Liquid Waste contractor will begin a process referred to as SCIX to disposition salt solution in fiscal year 2014. In the first step of the process, salt solution retrieved from various waste tanks will be struck with Monosodium Titanate (MST) to remove key actinides and Sr. The salt solution will then be processed using Rotary Micro Filtration (RMF) to remove the MST and any insoluble solids. The MST and insoluble solids will accumulate on the bottom of Tank 41. The filtrate from RMF will be fed to ion exchange columns, also in Tank 41, to remove the ${ }^{137}$ Cs using Crystalline Silicotitanate (CST) resin. The decontaminated salt solution from SCIX will be sent to the Saltstone Facility for immobilization in grout. The ${ }^{137}$ Cs-laden CST resin will be sluiced and ground for particle size reduction, then sent to the DWPF for immobilization in glass. These processes mirror the current disposition paths for streams associated with the Salt Waste Processing Facility (SWPF), which is under construction and will run concurrently with SCIX.

The MST and insoluble solids from Tank 41 will periodically be transferred to a sludge batch preparation tank (e.g., Tank 42 or Tank 51) as part of the High Level Waste (HLW) sludge batch preparation process for DWPF. The ground, ${ }^{137}$ Cs-laden CST material (hereafter referred to simply as CST) from SCIX will be periodically transferred to Tank 40 prior to being processed at DWPF. Periodic additions of CST to Tank 40 would result in a changing composition of each sludge batch as it is processed since Tank 40 serves as the feed tank for the DWPF. Work is currently in progress to determine the feasibility of depositing the ground CST in Tank 41. If ground CST can be deposited in Tank 41 (depending on heat loading issues, among others), the CST would be sent to Tank 42 or Tank 51 using an existing transfer line. Therefore, the studies of SCIX impacts on DWPF glass formulation have encompassed scenarios where the CST is sent to either Tank 40 or to a sludge batch preparation tank. MST from the SWPF was also considered in the study.

The MST and CST from the SCIX process will significantly increase the concentrations of $\mathrm{Nb}_{2} \mathrm{O}_{5}$, $\mathrm{TiO}_{2}$, and $\mathrm{ZrO}_{2}$ in the DWPF feed. Other constituents of MST and CST $-\mathrm{Na}_{2} \mathrm{O}$ and $\mathrm{SiO}_{2}-$ are already present in high concentrations in DWPF glass; thus their influences are well understood. The increased concentrations of $\mathrm{Nb}_{2} \mathrm{O}_{5}, \mathrm{TiO}_{2}$, and $\mathrm{ZrO}_{2}$ will likely have some impact on the properties and performance of the DWPF glass product. Properties such as the liquidus 
temperature, viscosity, and rate of melting of the glass may be impacted. The performance of the glass, particularly its chemical durability as it pertains to repository acceptance requirements, may also be impacted. The DWPF uses a set of semi-empirical and first-principles models referred to as the Product Composition Control System (PCCS) ${ }^{3}$ to predict the properties and performance of a glass based on its composition, since it is not possible to measure these attributes during processing. The objective of this study was to evaluate the impacts of the SCIX streams on the properties and performance of the DWPF glass product and on the applicability of the current process control models. ${ }^{\text {a }}$ Any anticipated issues with model applicability or performance of the glass product were to be identified, and recommendations were to be made for addressing these issues.

\subsection{Liquidus Temperature Studies}

The liquidus temperatures $\left(\mathrm{T}_{\mathrm{L}}\right)^{\mathrm{b}}$ of select study glasses were determined using the isothermal heat treatment method. ${ }^{5}$ The temperature profiles of the furnaces were carefully determined and periodically verified. ${ }^{6}$ All thermocouples and temperature measurement devices were calibrated and periodically verified by the Savannah River National Laboratory (SRNL) Measurement and Test Equipment (M\&TE) program. A standard glass composition was incorporated periodically into the test glass matrix as a method of verifying the measured data. ${ }^{\mathrm{C}}$ Polished samples of each quenched glass were observed via optical microscopy prior to $T_{L}$ measurement to determine whether any preexisting spinel crystals were present. Quenched glasses that were found to contain spinel crystals were excluded from testing. The study glasses were ground and heat treated for 24 hours in platinum-alloy boats with tight fitting lids following the procedure. ${ }^{5}$ The glasses were air quenched after being removed from the furnace, then sectioned and polished for microscopy. ${ }^{7}$ Any bulk crystallization (as opposed to surface or interface crystallization) that occurred during the isothermal heat treatments was identified by optical microscopy. The procedure was repeated over various temperatures to determine the $T_{L}$ to within a narrow range of tolerance (typically $+/-5^{\circ} \mathrm{C}$ ).

Observations of crystallization within all of the study glasses during the $T_{L}$ evaluations via optical and scanning electron microscopy indicated that the primary crystalline phases forming were spinels, including $\mathrm{TiFe}_{2} \mathrm{O}_{4}$.

Liquidus temperatures were determined for the KT01-series glasses only. ${ }^{\mathrm{d}}$ In the interest of reducing the time necessary for further measurements, the $T_{L}$ values for the KT03, KT04, KT06, KT07, and KT10-series glasses were estimated. The isothermal heat treatment method described above was continued, although a smaller number of heat treatments were performed in order to estimate the $T_{L}$ for each glass over a broader range of temperature while supporting comparisons with the model predicted $T_{L}$ values. The temperature range for each composition was chosen to fall within the $95 \%$ confidence interval of the model predicted $\mathrm{T}_{\mathrm{L}}$ value for that composition (based on measured composition data).

\footnotetext{
${ }^{a}$ Fox and Edwards provide a more detailed discussion of the potential impacts of SCIX material on PCCS model predictions. $^{4}$

${ }^{b}$ Note that for DWPF-type glasses, $\mathrm{T}_{\mathrm{L}}$ is defined as the spinel liquidus temperature, or the maximum temperature at which the molten glass and the spinel crystalline phase are at equilibrium.

' See B. J. Riley et al., "International Round-Robin Study on Liquidus Temperature,” submitted for publication in International Journal of Applied Glass Science (2011). Measurements of the standard glass, referred to as ARG-1, consistently fell within the reported $\mathrm{T}_{\mathrm{L}}$ range of $1024-1046{ }^{\circ} \mathrm{C}$ for this composition.

${ }^{d}$ The $T_{L}$ data for the KT01-series glasses have been reported previously, ${ }^{4}$ but will be repeated here to provide a comprehensive summary.
} 
Liquidus temperatures for the KT02-series glasses were not measured due to their unrealistically high $\mathrm{TiO}_{2}$ concentrations. These compositions were selected to meet other objectives, as will be described in Section 4.2.1. Liquidus temperatures were not measured for the KT05 and KT09series glasses since they were expected to form crystalline phases at or near the melt temperature. Liquidus temperatures were not measured for the KT08-series glasses since they contained uranium and thorium, and a $\mathrm{T}_{\mathrm{L}}$ measurement capability for radioactive glasses is not currently available at SRNL.

The results of the $T_{L}$ measurements for the KT01-series glasses are shown graphically in Figure 3-1. The predicted and measured $T_{L}$ values for each KT01-series glass are also included in Table A-1 in Appendix A. A review of Figure 3-1 shows that seven of the KT01-series glasses had measured $\mathrm{T}_{\mathrm{L}}$ values that fell within the 95\% confidence intervals of the model predicted values. Note that crystals were present in the quenched version of glass KT01-HK; therefore, a $\mathrm{T}_{\mathrm{L}}$ value could not be measured for this composition. The remaining four glasses had measured $\mathrm{T}_{\mathrm{L}}$ values that were higher than the upper 95\% confidence interval bound. Overall, the model under predicted the $\mathrm{T}_{\mathrm{L}}$ for all of these glasses with elevated $\mathrm{TiO}_{2}$ concentrations (target values of $8 \mathrm{wt} \% \mathrm{TiO}_{2}$ ), although the trends between the measured and model predicted data appeared to be consistent and several of the measured $\mathrm{T}_{\mathrm{L}}$ values fell within the $95 \%$ confidence bands. One must keep in mind that these $\mathrm{TiO}_{2}$ concentrations were well above the region of applicability defined for the current $\mathrm{T}_{\mathrm{L}}$ model of $0-1.8549 \mathrm{wt} \% \mathrm{TiO}_{2}$; therefore, this prediction bias is not necessarily unexpected. ${ }^{8}$

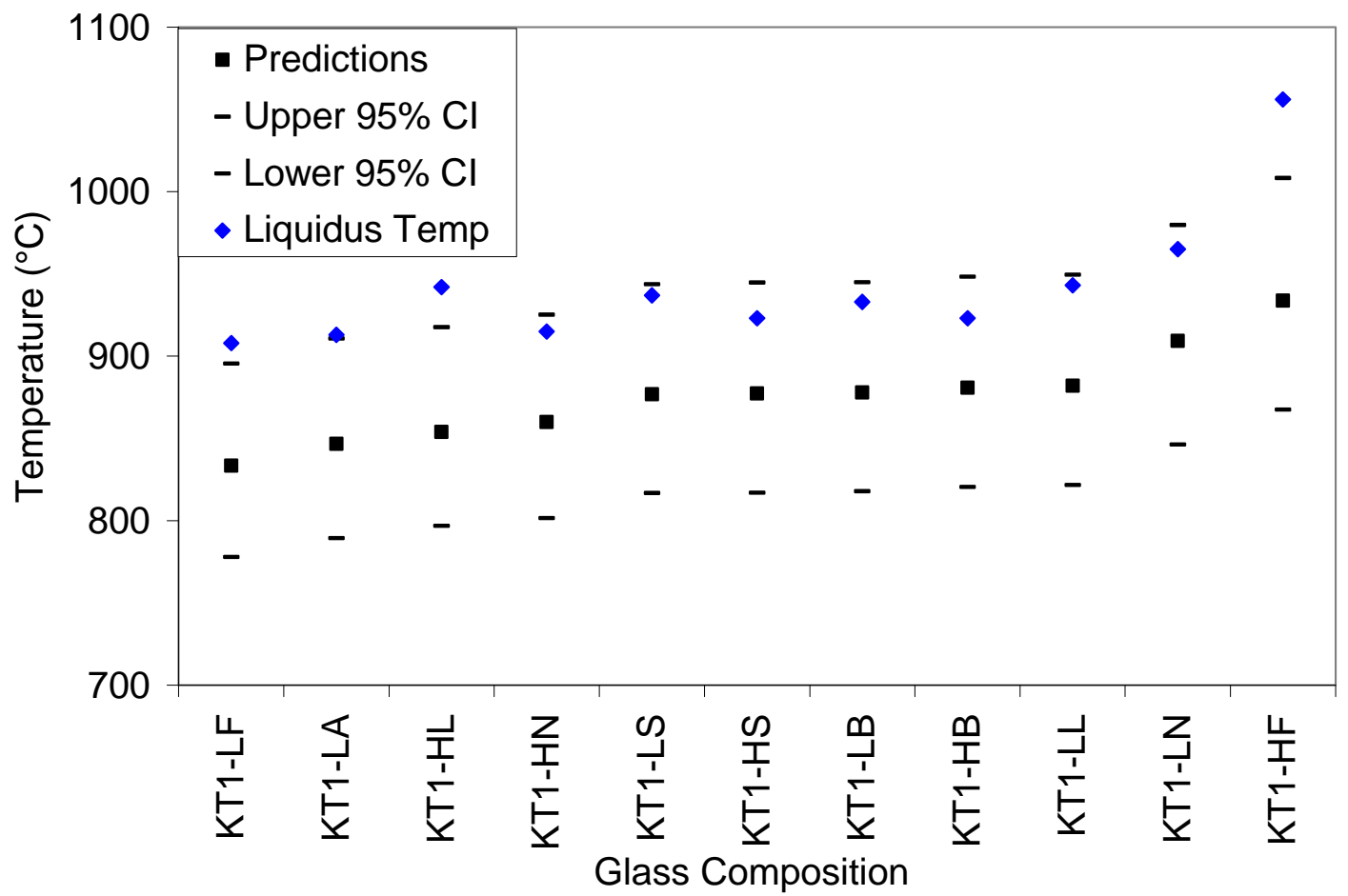

Figure 3-1. Liquidus Temperature Measurements for the KT01-Series Glasses.

The estimated $T_{L}$ values for the KT03-series glasses are shown graphically in Figure 3-2. The predicted and estimated $T_{L}$ values for each KT03-series glass are also included in Table A-2 in Appendix A. A review of Figure 3-2 shows that most of the estimated $T_{L}$ values (between the temperature of the blue data point where no crystals were present and the temperature of the red 
data point where crystallization had occurred) fall within the $95 \%$ confidence interval of the model predicted values. Composition KT03-HL, a high $\mathrm{Li}_{2} \mathrm{O}$ concentration glass, has a $\mathrm{T}_{\mathrm{L}}$ that is very close the upper $95 \%$ confidence interval bound for the predicted $\mathrm{T}_{\mathrm{L}}$. All of the KT03-series glasses had crystals present at or above the predicted $\mathrm{T}_{\mathrm{L}}$ values, again indicating that the current model is under predicting the $\mathrm{T}_{\mathrm{L}}$ of glasses with high $\mathrm{TiO}_{2}$ concentrations $\left(8 \mathrm{wt} \% \mathrm{TiO}_{2}\right.$ for the KT03-series). Note that the $\mathrm{T}_{\mathrm{L}}$ could not be estimated for compositions KT03-HK and KT03-MK since crystals were visible via optical microscopy in the quenched versions of these glasses. ${ }^{\mathrm{a}}$

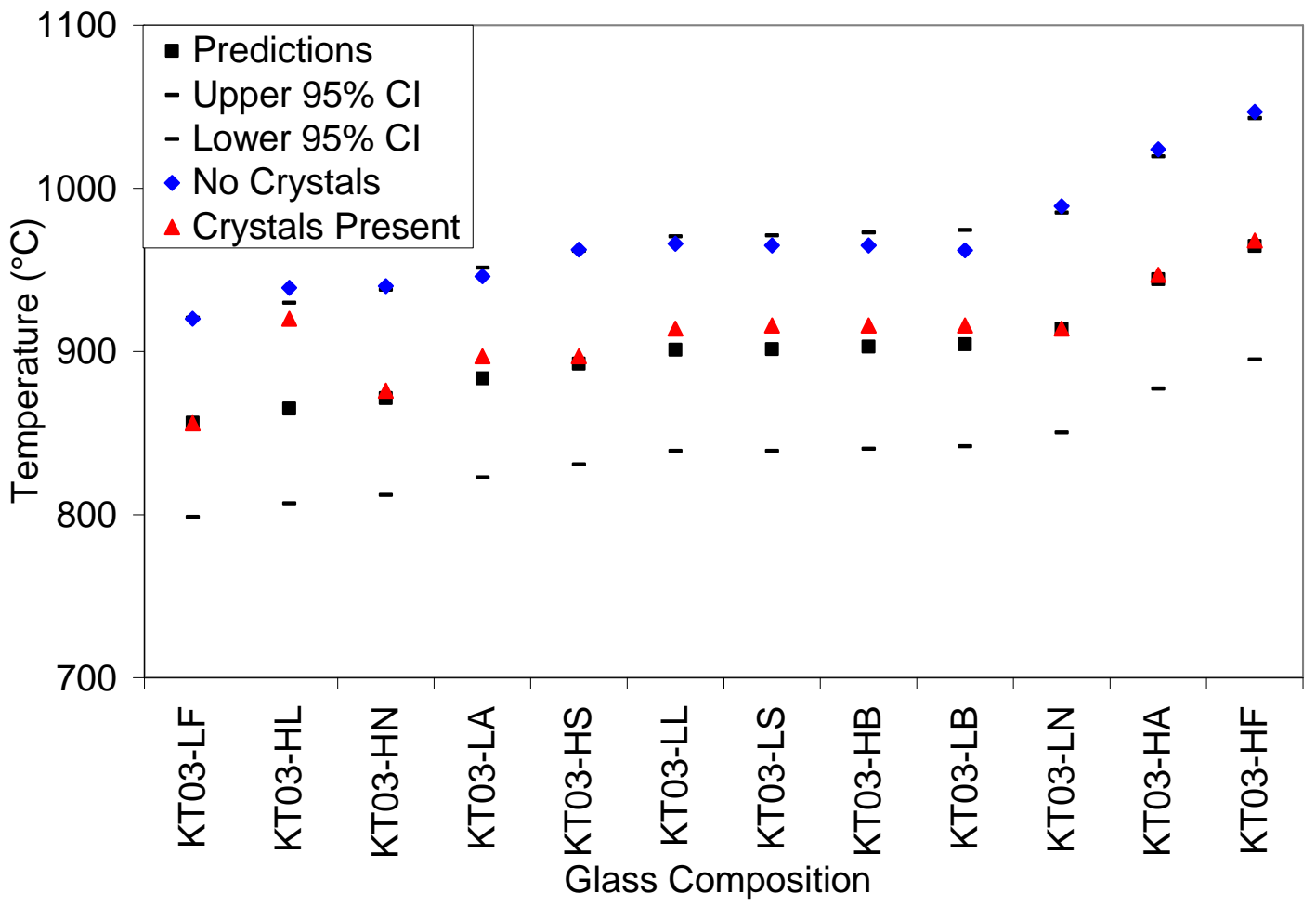

Figure 3-2. Liquidus Temperature Estimates for the KT03-Series Glasses.

The estimated $T_{L}$ values for the KT04-series glasses are shown graphically in Figure 3-3. The predicted and estimated $T_{L}$ values for each KT04-series glass are also included in Table A-2 in Appendix A. A review of Figure 3-3 and comparison with Figure 3-2 shows that the results are quite similar to those for the KT03-series glasses. Most of the estimated $\mathrm{T}_{\mathrm{L}}$ values for the KT04series glasses fall within the $95 \%$ confidence interval of the model predicted values, although all of the KT04-series glasses had crystals present at or above the predicted $\mathrm{T}_{\mathrm{L}}$ values. These data continue to show a bias in the current model predicted $\mathrm{T}_{\mathrm{L}}$ values for glasses with high $\mathrm{TiO}_{2}$ concentrations (4-5 wt \% $\mathrm{TiO}_{2}$ for the KT04-series).

\footnotetext{
a As will be discussed in Section 4.2.1, these glass compositions were selected to determine the impact of high potassium concentrations on titanium incorporation and are very unlikely for actual DWPF processing.
} 


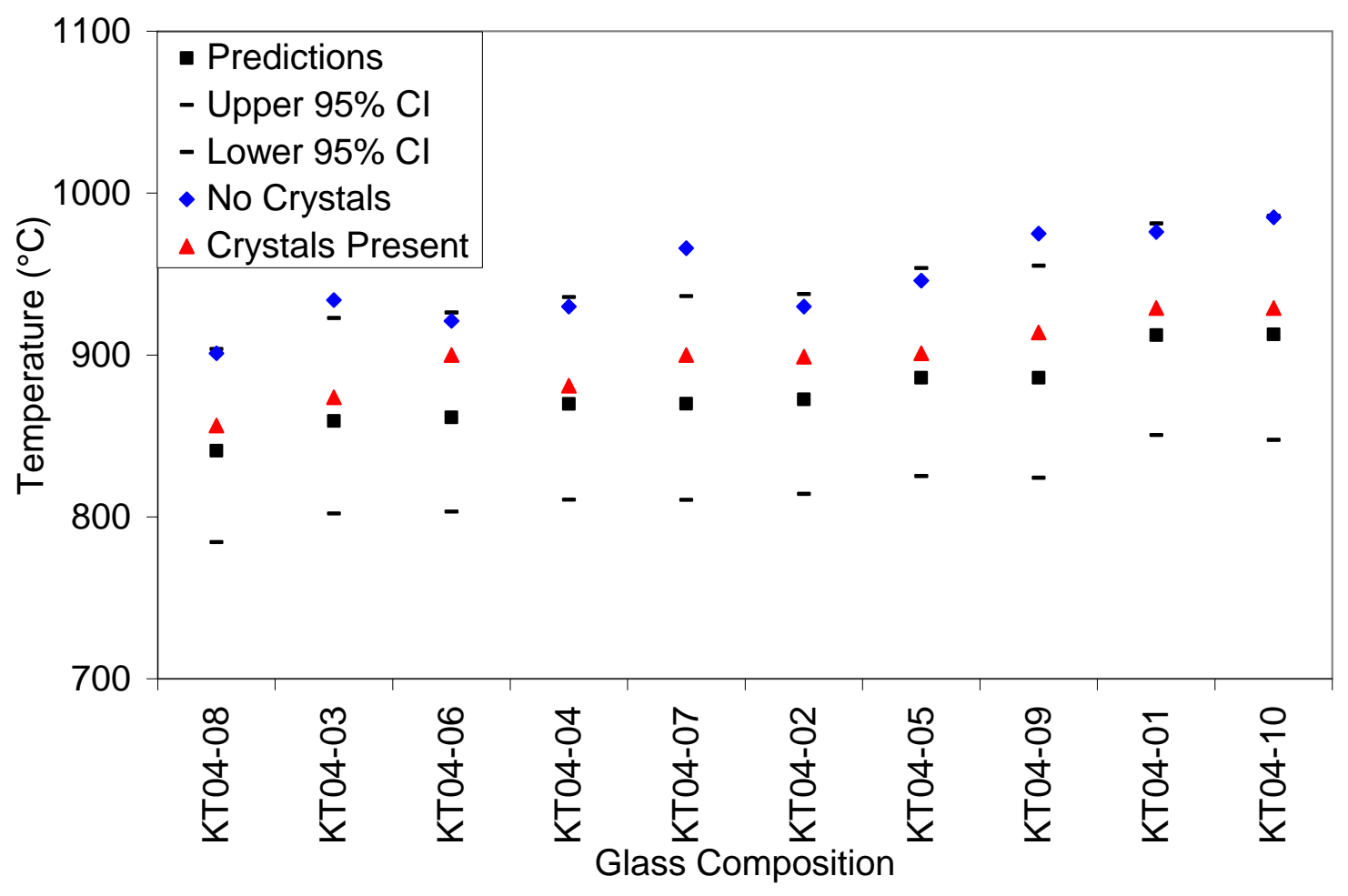

Figure 3-3. Liquidus Temperature Estimates for the KT04-Series Glasses.

The estimated $T_{L}$ values for the KT06-series glasses are shown graphically in Figure 3-4. The predicted and estimated $T_{L}$ values for each KT06-series glass are also included in Table A-2 in Appendix A. A review of Figure 3-4 shows that the estimated $T_{L}$ values for most of the KT06series glasses fall within the 95\% confidence interval for the model predicted values. Compositions KT06-04, -13 , and -16 had crystals present at or very close to the upper 95\% confidence interval bound for the predicted $\mathrm{T}_{\mathrm{L}}$. This indicates that the current model under predicts the $\mathrm{T}_{\mathrm{L}}$ for these three compositions. Composition KT06-12 was free of crystallization at a temperature of $20^{\circ} \mathrm{C}$ above the predicted $\mathrm{T}_{\mathrm{L}}$, indicating that there may not be an issue with under prediction for this particular composition. All of the other KT06-series glasses had crystals present at or above the predicted $\mathrm{T}_{\mathrm{L}}$ values, again indicating that the current model is under predicting the $\mathrm{T}_{\mathrm{L}}$ of glasses with high $\mathrm{TiO}_{2}$ concentrations (6 wt $\% \mathrm{TiO}_{2}$ for the KT06-series). 


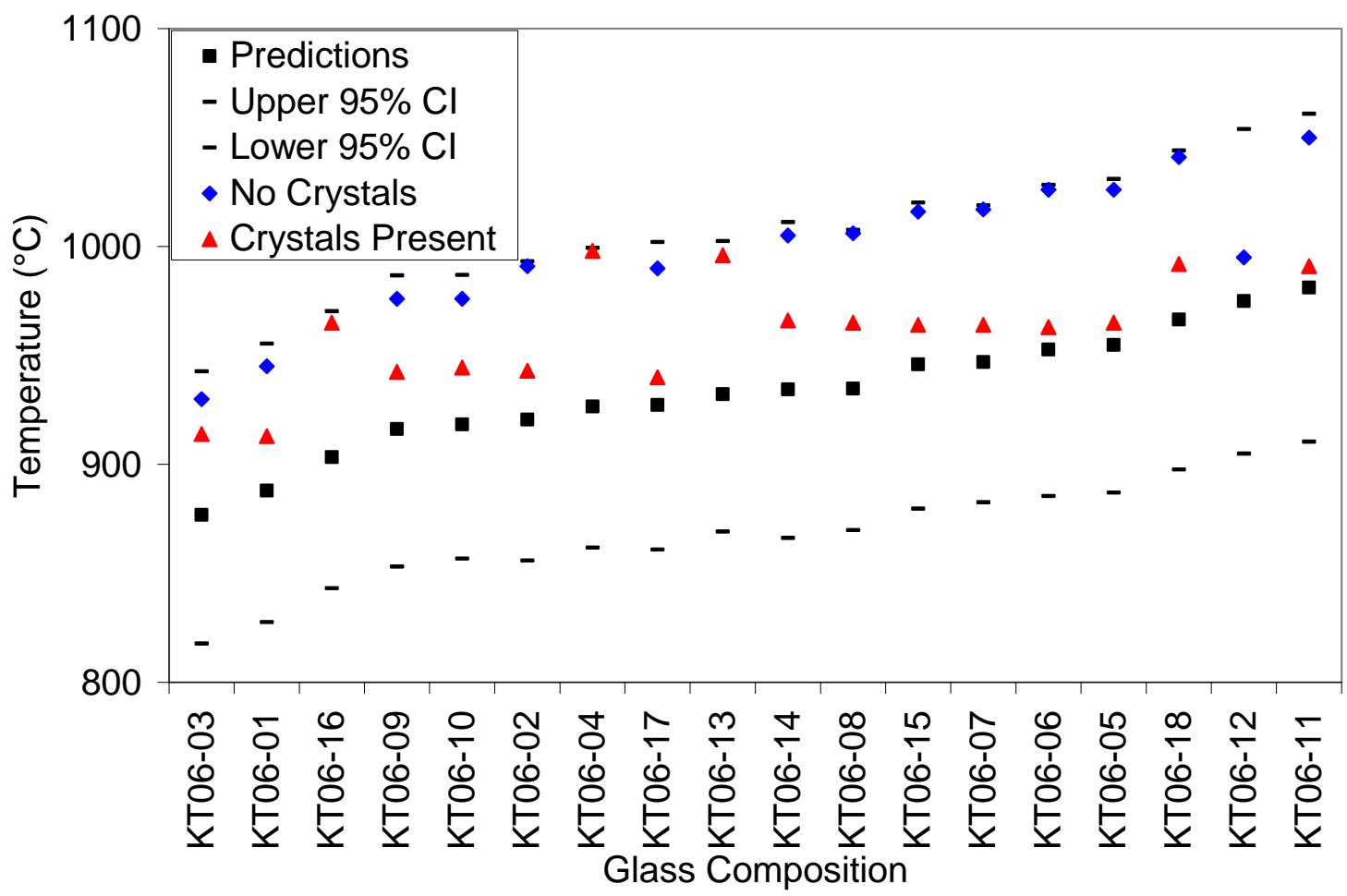

Figure 3-4. Liquidus Temperature Estimates for the KT06-Series Glasses.

The estimated $T_{L}$ values for the KT07-series glasses are shown graphically in Figure 3-5. The predicted and estimated $T_{L}$ values for each KT07-series glass are also included in Table A-2 in Appendix A. A review of Figure 3-5 shows that all of the glasses had crystals present at temperatures that were at or very close to the upper bound of the $95 \%$ confidence interval of the model predicted $\mathrm{T}_{\mathrm{L}}$ value. A major difference between the KT07-series and the earlier KT-series glasses is the inclusion of noble metals in the KT07-series. ${ }^{\mathrm{a}}$ At first glance, it may appear that the addition of noble metals to these glasses has increased their $\mathrm{T}_{\mathrm{L}}$ values as compared to the earlier glasses that did not contain noble metals. However, previous work in developing TimeTemperature-Transformation (TTT) diagrams for SRS waste glass has shown a strong kinetic effect of noble metals, particularly $\mathrm{RuO}_{2}$, on the crystallization of spinels and acmite. ${ }^{\mathrm{b}}$ The inclusion of noble metals does not change the liquidus temperature, but significantly reduces the time necessary for crystallization to occur in a given composition at a given temperature. Thus, the implication is that the heat treatment time of 24 hours used in the liquidus temperature estimates where noble metals were not present may not have been sufficient to allow crystallization to occur. When noble metals were included, the time necessary for crystallization was less than 24 hours, giving the results shown in Figure 3-5.

\footnotetext{
a The KT07-series glasses used the same target compositions as the KT04-series glasses, except that sulfur and the noble metals Ag, Pd, Rh, and Ru were added to the KT07-series glasses. ${ }^{9}$

${ }^{\mathrm{b}}$ C. M. Jantzen and D. F. Bickford, TTT Diagrams of SRL 165 Waste Glasses, unpublished results.

${ }^{\mathrm{c}}$ As a further example, compare the data for composition KT04-10 in Figure 3-3 (no crystals present after 24 hours at $985^{\circ} \mathrm{C}$ ) with the data for composition KT07-10 in Figure 3-5 (spinel crystals present after 24 hours at $999{ }^{\circ} \mathrm{C}$ ). The noble metals in composition KT07-10 may have reduced the time necessary for spinel crystallization in this composition to less than 24 hours in this temperature range. Heat treating KT04-10 at this temperature for a period longer than 24 hours may therefore lead to spinel crystallization.
} 
Additional heat treatments were performed for glasses KT07-02, -03, -04, -06, -07, and -08 at higher temperatures to ensure that a crystal-free temperature could be identified for some of the KT07 compositions. As shown by the blue data points in Figure 3-5, the heat treatments at higher temperatures did produce crystal-free glasses for these compositions where noble metals are included. The estimates for these compositions indicate that the actual liquidus temperatures of these glasses may still fall below the current DWPF limit (without uncertainties applied) of $1050{ }^{\circ} \mathrm{C}$. The results for all of the KT07-series glasses indicate that the measured ranges of the $\mathrm{T}_{\mathrm{L}}$ values are well above the model predicted values for these glass compositions (4-5 wt \% $\mathrm{TiO}_{2}$ for the KT-07 series).

Overall, the result of these $T_{L}$ estimates is the same as seen in the previous KT-series glasses: the model predicted $T_{L}$ values are lower than the estimated $T_{L}$ values (based on measured data) for the high $\mathrm{TiO}_{2}$ concentration glasses. The amount of bias in the predicted values is likely to be larger than was apparent with the glasses that did not include noble metals, since the heat treatment time for the earlier series of glasses may have been too short.

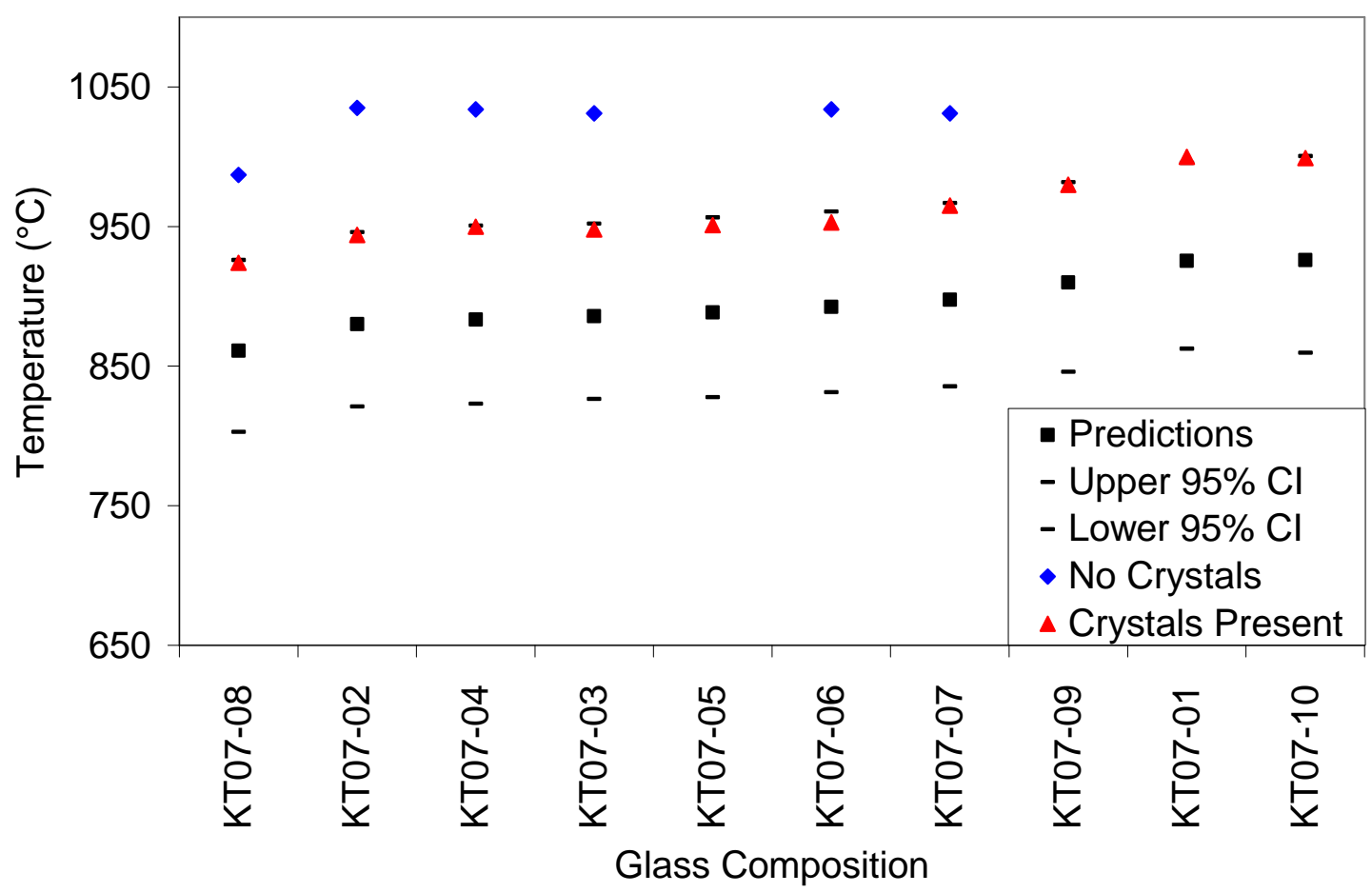

Figure 3-5. Liquidus Temperature Estimates for the KT07-Series Glasses.

The estimated $T_{L}$ values for the KT10-series glasses are shown graphically in Figure 3-6. The predicted and estimated $T_{L}$ values for each KT10-series glass are also included in Table A-2 in Appendix A. A review of Figure 3-6 shows that all of the glasses had crystals present at temperatures that were at or very close to the upper bound of the $95 \%$ confidence interval of the model predicted $\mathrm{T}_{\mathrm{L}}$ value. The KT10-series glasses contained noble metals, and the results are very similar to those for the KT07-series glasses. Crystallization at higher temperatures was not determined since the data in Figure 3-6 were sufficient to show a continued trend of the current model predicting a $\mathrm{T}_{\mathrm{L}}$ value below the actual value for high $\mathrm{TiO}_{2}$ concentration glasses $(6-7 \mathrm{wt} \%$ $\mathrm{TiO}_{2}$ for the KT10-series). 


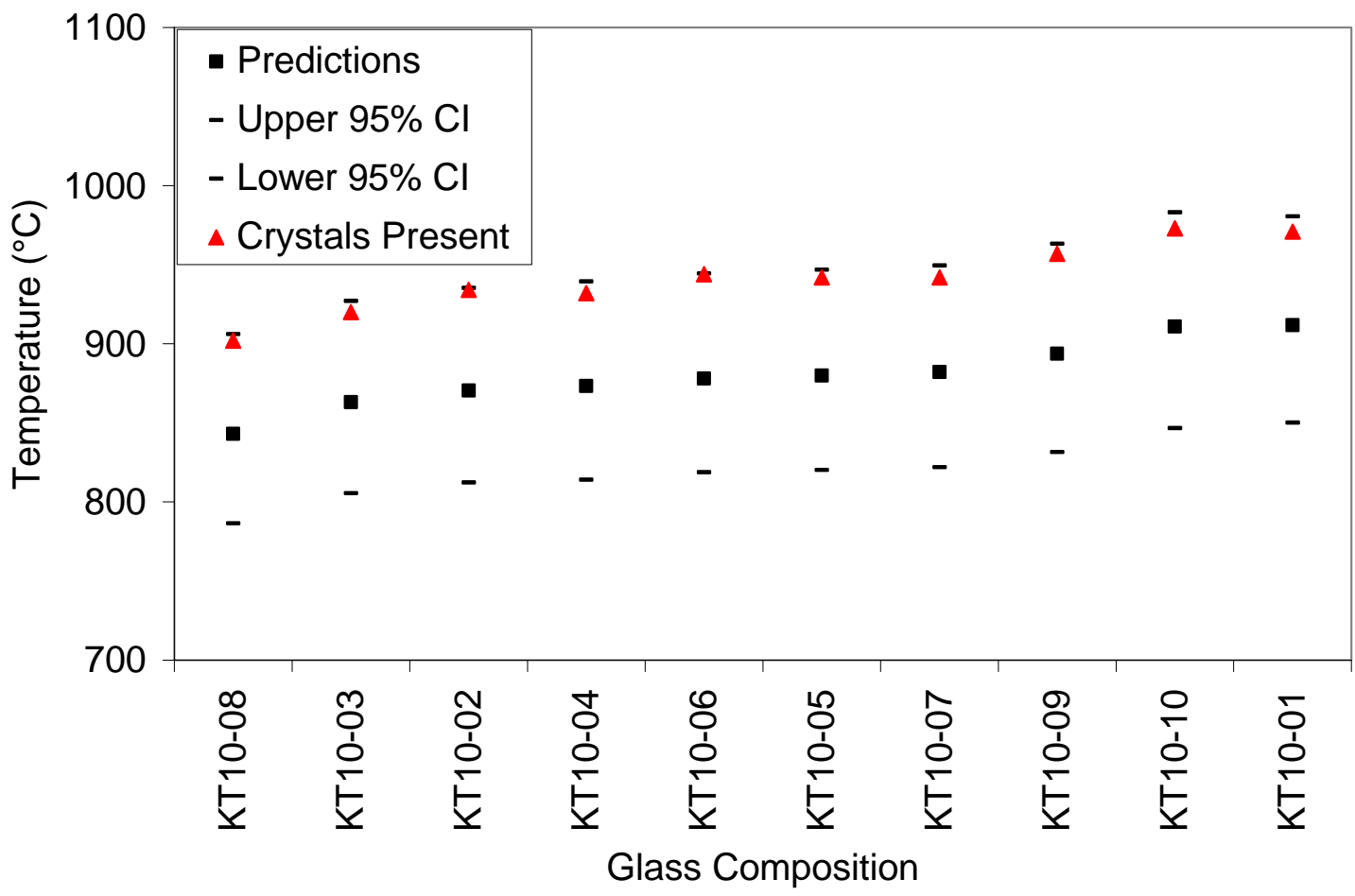

Figure 3-6. Liquidus Temperature Estimates for the KT10-Series Glasses.

In summary, the measured and estimated liquidus temperatures for the KT-series glasses demonstrate a prediction bias in the current $\mathrm{T}_{\mathrm{L}}$ model for high $\mathrm{TiO}_{2}$ concentration glasses. The current model predicted $\mathrm{T}_{\mathrm{L}}$ values are lower than the measured or estimated values for almost all of the study glasses. The inclusion of noble metals indicates that the heat treatment times may need to be increased for future liquidus temperature measurements, although the time period used here did not impact the trend of the current model under predicting the measured $T_{L}$ data. It is important to note that these $\mathrm{TiO}_{2}$ concentrations are well above the region of applicability defined for the current $\mathrm{T}_{\mathrm{L}}$ model of $0-1.8549 \mathrm{wt} \% \mathrm{TiO}_{2}{ }^{8}$ therefore, the issues identified are not necessarily unexpected.

Observations of crystallization within all of the study glasses during the $\mathrm{T}_{\mathrm{L}}$ evaluations via optical and scanning electron microscopy indicated that the primary crystalline phases forming were spinels, including $\mathrm{TiFe}_{2} \mathrm{O}_{4}$. The formation of spinels is consistent with the development of the current $\mathrm{T}_{\mathrm{L}}$ model in that the model is designed to predict the spinel liquidus temperature from glass composition. ${ }^{3}$

As mentioned earlier, the measured $\mathrm{T}_{\mathrm{L}}$ values for the KT01-series glasses (the only series where $T_{L}$ values were measured rather than estimated) were under predicted by the current model, but the trend between the measured and the predicted values was consistent. In other words, there was a fairly consistent offset between the predicted and measured values, rather than random differences. This offset may indicate that the coefficients of the model can be refit in order to eliminate the prediction bias for glasses with high $\mathrm{TiO}_{2}$ concentrations, while the mechanistic basis of the model remains valid. In fact, Brown et al. recommended that if compositions outside the composition space of the model development glasses become likely for DWPF processing then the model may have to be adjusted. ${ }^{8}$ Therefore, the path forward for the $T_{L}$ model evaluation work will be to measure actual $\mathrm{T}_{\mathrm{L}}$ values (rather than estimates) for the KT-series 
glasses. These data will then allow for further evaluation to determine whether the coefficients of the current $\mathrm{T}_{\mathrm{L}}$ model can be refit to better predict the $\mathrm{T}_{\mathrm{L}}$ values of the high $\mathrm{TiO}_{2}$ concentration glasses.

\subsection{Summary of Studies of Potential Impacts of SCIX on DWPF Glass Formulation}

\subsection{Results of the Paper Study}

Fox and Edwards performed a paper study evaluation using updated projections for sludge batch compositions and SCIX CST and MST addition rates. ${ }^{10}$ This paper study evaluated composition projections for Sludge Batches 8 through 17 with MST added during batch preparation and with CST added to either Tank 40 or Tank 42/51. Additions of CST to Tank 40 were made incrementally during processing, while additions of CST to Tank 42/51 were made in a single transfer. Two production rates were evaluated, along with the inclusion or exclusion of SWPF streams. The sludge compositions (a total of 120) were evaluated with an array of 1,144 candidate frit compositions using Nominal Stage Measurement Acceptability Region (MAR) assessments with the DWPF PCCS models.

This study found that, as a result of the updated composition projections, ${ }^{\text {a }}$ several viable options were predicted to be available for incorporation of the SCIX streams, with CST being sent to either Tank 40 or a sludge batch preparation tank. Transfer of the CST to a sludge batch preparation tank was the preferred option since it allowed more compositional flexibility for frit optimization while maintaining sufficient projected operating windows. The report identified several assumptions and limitations associated with the current PCCS models, and recommended that these be further evaluated. The experimental program was therefore developed to provide the data necessary to address many of these assumptions.

\subsection{Results of the Experimental Studies}

Ten series of glass compositions were selected and characterized in support of the SCIX program. Each series was labeled with the identifier KT. The results for each series of glasses have been documented in separate reports, and they will be reviewed and summarized here. Table 4-1 provides an overview of the objectives and outcomes for each series of glasses. These results will be reviewed in further detail in the following sections.

\footnotetext{
a A similar study by Peeler and Edwards in 2007 determined that the periodic addition of CST to Tank 40 was not a viable option in terms of producing PCCS acceptable glass compositions. ${ }^{11}$
} 
Table 4-1. Summary of Studies for SCIX Impacts on DWPF Glass Formulation.

\begin{tabular}{|c|c|c|c|}
\hline Study ID & Objectives & Outcomes & Reference \\
\hline KT01 & $\begin{array}{l}\text { - Study impacts of individual oxides } \\
\text { on incorporation of } 8 \mathrm{wt} \% \mathrm{TiO}_{2}\end{array}$ & $\begin{array}{l}\text { - No crystallization of Ti-containing phases observed, regardless of whether they } \\
\text { were quenched or subjected to the canister centerline cooled (CCC) heat treatment } \\
\text { - No obvious effects of individual oxides } \\
\text { - Durability was acceptable and generally predictable } \\
\text { - Viscosity was acceptable and generally predictable } \\
\text { - Liquidus temperatures higher than predicted }\end{array}$ & 4 \\
\hline KT02 & $\begin{array}{l}\text { - Study impacts of individual oxides } \\
\text { on incorporation of } 12 \mathrm{wt} \% \mathrm{TiO}_{2}\end{array}$ & $\begin{array}{l}\text { - Ti-containing crystals formed in several compositions during the CCC heat } \\
\text { treatment } \\
\text { - Increased } \mathrm{Na}_{2} \mathrm{O} \text { and } \mathrm{K}_{2} \mathrm{O} \text { concentrations appeared to hinder the formation of these } \\
\text { phases }\end{array}$ & 4 \\
\hline KT03 & $\begin{array}{l}\text { - Study impacts of individual oxides } \\
\text { on incorporation of } 8 \mathrm{wt} \% \mathrm{TiO}_{2} \text { with } 3 \\
\text { wt } \% \mathrm{Nb}_{2} \mathrm{O}_{5} \text { and } 2.5 \mathrm{wt} \% \mathrm{ZrO}_{2}\end{array}$ & $\begin{array}{l}\text { - No crystallization of Ti-containing phases observed, regardless of whether they } \\
\text { were quenched or subjected to the CCC heat treatment } \\
\text { - No obvious effects of individual oxides } \\
\text { - Durability was acceptable and generally predictable } \\
\text { - Viscosity was acceptable and generally predictable } \\
\text { - Most estimated liquidus temperatures fell within the range of the current model } \\
\text { predictions }\end{array}$ & 4 \\
\hline KT04 & $\begin{array}{l}\text { - Study PCCS MAR acceptable glasses } \\
\text { based on LWO projections of SB8 } \\
\text { through SB17 with CST added to Tank } \\
\text { 40, at the final SRAT batch } \text { (TiO }_{2} 4.3- \\
5.0 \text { wt \% in glass) }\end{array}$ & $\begin{array}{l}\text { - All glasses remained amorphous regardless of whether they were quenched or } \\
\text { subjected to the CCC heat treatment } \\
\text { - Viscosity and durability were acceptable and predictable } \\
\text { - Most estimated liquidus temperatures fell within the range of the current model } \\
\text { predictions, although they were all greater than the predicted values }\end{array}$ & 4 \\
\hline KT05 & $\begin{array}{l}\text { - Study the effect of } \mathrm{Na}_{2} \mathrm{O} \text { on glasses } \\
\text { known to form crystals containing } \\
\mathrm{TiO}_{2}\end{array}$ & $\begin{array}{l}\text { - Ti-containing phases formed, although } \mathrm{Na}_{2} \mathrm{O} \text { had little, if any, impact } \\
\text { - Recommended studying effects of } \mathrm{Al}_{2} \mathrm{O}_{3} \text { and } \mathrm{K}_{2} \mathrm{O}\end{array}$ & 12 \\
\hline KT06 & $\begin{array}{l}\text { - Study PCCS MAR acceptable glasses } \\
\text { with wide variation placed around the } \\
\text { SB8 to SB17 composition region }\left(\mathrm{TiO}_{2}\right. \\
6 \mathrm{wt} \% \text { in glass) }\end{array}$ & $\begin{array}{l}\text { - Ti-containing phases observed in some glasses after the CCC heat treatment } \\
\text { - All durability values were acceptable, although some were not predictable } \\
\text { (combination of high } \mathrm{TiO}_{2}, \mathrm{Fe}_{2} \mathrm{O}_{3} \text {, and } \mathrm{Al}_{2} \mathrm{O}_{3} \text { ) } \\
\text { - All viscosity values were acceptable, although some were not predictable } \\
\text { (combination of high } \mathrm{TiO}_{2} \text { and low } \mathrm{Fe}_{2} \mathrm{O}_{3} \text { ) } \\
\text { - Most estimated liquidus temperatures fell within the range of the current model } \\
\text { predictions }\end{array}$ & 12 \\
\hline
\end{tabular}


Table 4-1. Summary of Studies for SCIX Impacts on DWPF Glass Formulation. (continued)

\begin{tabular}{|c|c|c|c|}
\hline Study ID & Objectives & $\begin{array}{c}\text { Outcomes } \\
\end{array}$ & Reference \\
\hline KT07 & $\begin{array}{l}\text { - Similar to KT04, but with noble } \\
\text { metals added }\end{array}$ & $\begin{array}{l}\text { - All glasses remained amorphous regardless of whether they were quenched or } \\
\text { subjected to the CCC heat treatment } \\
\text { - Viscosity and durability were acceptable and predictable } \\
\text { - Liquidus temperatures are not well predicted }\end{array}$ & 9 \\
\hline KT08 & $\begin{array}{l}\text { - Similar to KT04, but with noble } \\
\text { metals, thorium, and uranium added }\end{array}$ & $\begin{array}{l}\text { - All but one of the glasses remained amorphous, regardless of whether they were } \\
\text { quenched or subjected to the CCC heat treatment } \\
\text { - Durability was acceptable and predictable } \\
\text { - Viscosity was acceptable and generally predictable } \\
\text { - No unexpected effects when uranium and thorium were included } \\
\text { - Liquidus temperature not measured for radioactive glasses }\end{array}$ & 13 \\
\hline KT09 & $\begin{array}{l}\text { - Study the effects of } \mathrm{Al}_{2} \mathrm{O}_{3} \text { and } \mathrm{K}_{2} \mathrm{O} \\
\text { on glasses known to form crystals } \\
\text { containing } \mathrm{TiO}_{2}\end{array}$ & $\begin{array}{l}\text { - Increased } \mathrm{Al}_{2} \mathrm{O}_{3} \text { concentrations not successful in preventing crystallization of iron } \\
\text { titanates } \\
\text { - Increased } \mathrm{K}_{2} \mathrm{O} \text { concentrations successful in hindering crystallization of iron } \\
\text { titanates in some of the glasses after the CCC heat treatment, although results were } \\
\text { dependent upon composition }\end{array}$ & 13 \\
\hline KT10 & $\begin{array}{l}\text { - Similar to KT04, but with noble } \\
\text { metals added and with } \mathrm{Nb}_{2} \mathrm{O}_{5}, \mathrm{TiO}_{2} \text {, } \\
\text { and } \mathrm{ZrO}_{2} \text { concentrations increased to } \\
150 \% \text { of projected maximums } \\
\left(\mathrm{TiO}_{2} 6-7 \text { wt \% in glass) }\right.\end{array}$ & $\begin{array}{l}\text { - All glasses remained amorphous regardless of whether they were quenched or } \\
\text { subjected to the CCC heat treatment } \\
\text { - Durability was acceptable and generally predictable } \\
\text { - Viscosity was acceptable and generally predictable } \\
\text { - Liquidus temperatures are not well predicted }\end{array}$ & 13 \\
\hline
\end{tabular}




\subsubsection{KT01 through KT04-Series Glasses}

The KT01 and KT02-series of glasses were designed to allow for the identification of the influence of the concentrations of major components of the glass on the incorporation of $\mathrm{TiO}_{2}$. The KT03-series of glasses was designed to allow for the identification of these influences when higher $\mathrm{Nb}_{2} \mathrm{O}_{5}$ and $\mathrm{ZrO}_{2}$ concentrations are included along with $\mathrm{TiO}_{2}$. The KT04-series of glasses was designed to investigate the properties and performance of glasses based on the best available projections of actual compositions to be processed at the DWPF (i.e., future sludge batches including the SCIX streams). The glasses were fabricated in the laboratory without the radioactive components. They were characterized using X-ray diffraction (XRD) to identify crystallization, inductively coupled plasma - atomic emission spectroscopy (ICP-AES) to verify chemical compositions, and the Product Consistency Test (PCT) to measure durability. The viscosity and liquidus temperature of several of the glasses were also measured.

The XRD results showed no titanium containing phases in the KT01-series glasses, regardless of whether they had been air quenched or slowly cooled using the CCC heat treatment. The targeted $\mathrm{TiO}_{2}$ concentration had to be increased to $12 \mathrm{wt} \%$ in glass in the KT02-series before any compositional impacts on $\mathrm{TiO}_{2}$ incorporation (e.g., the formation of titanium containing crystals) were apparent. Titanium containing crystalline phases formed in the CCC versions of all of the KT02 compositions except for the low $\mathrm{Al}_{2} \mathrm{O}_{3}$ concentration glass, the low $\mathrm{Fe}_{2} \mathrm{O}_{3}$ concentration glass, the high $\mathrm{Na}_{2} \mathrm{O}$ concentration glass, and the high $\mathrm{K}_{2} \mathrm{O}$ concentration glass. Note however that the $12 \mathrm{wt} \% \mathrm{TiO}_{2}$ concentrations in these glasses are unrealistic for DWPF processing with the SCIX streams and material from SWPF based on current projections. Spinels were identified in some of the KT03 glasses after the CCC heat treatment. The spinels did not adversely impact the durability of the glasses. The KT04-series glasses were amorphous regardless of whether they were quenched or subjected to the CCC heat treatment.

No issues were found upon review of the chemical composition measurements, nor were any issues found upon review of the PCT measurements. All of the glasses studied were considerably more durable than the benchmark Environmental Assessment (EA) glass. The measured PCT responses were compared with the predicted values from the current DWPF durability model. One of the KT01-series and two of the KT03-series glasses had measured PCT responses that were outside the lower bound of the durability model. All three of these glasses had intentionally high $\mathrm{K}_{2} \mathrm{O}$ concentrations (to evaluate the impact of $\mathrm{K}_{2} \mathrm{O}$ on $\mathrm{TiO}_{2}$ incorporation), which may indicate a lack of applicability for the durability model in this composition region. However, the lack of applicability in this region is likely of little practical importance since $\mathrm{K}_{2} \mathrm{O}$ concentrations of this magnitude are unrealistic for actual compositions to be processed at the DWPF. All of the KT04 glasses had durabilities that were predictable regardless of whether they were quenched or subjected to the CCC heat treatment.

All but two of the KT01, KT03, and KT04-series glasses had measured viscosities that were predictable using the current DWPF viscosity model. The viscosities of two of the high $\mathrm{K}_{2} \mathrm{O}$ concentration glasses, KT01-HK and KT03-MK, fell above the upper confidence intervals for the model predictions. These glasses have $\mathrm{K}_{2} \mathrm{O}$ concentrations that are above the DWPF viscosity model development range for $\mathrm{K}_{2} \mathrm{O} .{ }^{14}$ Another high $\mathrm{K}_{2} \mathrm{O}$ concentration glass, KT03-HK, had a measured viscosity that was well predicted by the current DWPF model. While these results indicate a lack of applicability for the DWPF viscosity model for increased $\mathrm{K}_{2} \mathrm{O}$ concentrations, it is again important to note that these $\mathrm{K}_{2} \mathrm{O}$ concentrations are unrealistic for actual DWPF processing. Overall, the measured viscosity values of the KT01, KT03, and KT04-series glasses were well predicted by the current DWPF viscosity model. The results of the $T_{L}$ measurements 
for the KT01 glasses and the $\mathrm{T}_{\mathrm{L}}$ estimates for the KT03 and KT04 glasses were discussed earlier in Section 3.0.

\subsubsection{KT05 and KT06-Series Glasses}

The KT05-series glasses were designed, fabricated, and characterized to further study HLW glass compositions where iron titanate crystals had been found to form. The intent was to better understand the mechanisms and compositions that favored the formation of crystals containing titanium. Formation of these crystalline phases was confirmed. Increased $\mathrm{Na}_{2} \mathrm{O}$ concentrations had little, if any, impact on reducing the propensity for the formation of the iron titanate crystalline phases. Other physical properties of these glasses were not measured since the intent was to focus on crystallization. It was recommended that the baseline compositions in the KT05series be further investigated to identify the potential influence of increased $\mathrm{K}_{2} \mathrm{O}$ and $\mathrm{Al}_{2} \mathrm{O}_{3}$ concentrations on hindering the formation of titanium-containing crystalline phases. As will be shown below, these recommendations were addressed in the design of the KT09-series glasses.

The KT06-series glasses were designed, fabricated, and characterized to further study HLW glass compositions that, while broader than the current projections for DWPF feeds with SCIX material, are potential candidates for future processing (i.e., the compositions are acceptable for processing by PCCS with the exception of the current $\mathrm{TiO}_{2}$ concentration constraint). The measured chemical compositions of these glasses were consistent with the targeted values. The PCT responses of all the glasses were acceptable relative to the EA benchmark. Minor spinel crystallization was identified in some of the CCC glasses, although this crystallization did not impact chemical durability. Estimates of the liquidus temperatures of the KT06-series glasses were discussed earlier in Section 3.0.

Several of the KT06-series compositions had durability values that were acceptable but were not well predicted by the current PCCS models. A similar lack of fit for model predicted durabilities for glasses with more positive $\Delta \mathrm{G}_{\mathrm{p}}$ values has been seen in previous studies of DWPF-type glasses. It was shown that for the high $\mathrm{TiO}_{2}$ concentration glasses $\left(6 \mathrm{wt} \% \mathrm{TiO}_{2}\right)$ in the $\mathrm{KT06}$ study, relatively high $\mathrm{Fe}_{2} \mathrm{O}_{3}$ concentrations combined with relatively high $\mathrm{Al}_{2} \mathrm{O}_{3}$ concentrations led to unpredictable durabilities. The current durability models will have to be further evaluated should compositions in this region become necessary for DWPF processing.

Several of the KT06-series glasses also had measured viscosity values that were not well predicted by the current model. A statistical partitioning routine showed that the measured viscosities became unpredictable by the current model when the $\mathrm{Fe}_{2} \mathrm{O}_{3}$ concentration in the glasses was less than about $8.2 \mathrm{wt} \%$ at the elevated $\mathrm{TiO}_{2}$ concentrations. The current viscosity model will have to be further evaluated should compositions in this region become necessary for DWPF processing. Note however that the KT06-series glasses were intentionally designed to cover compositional regions that are outside those currently projected for DWPF processing.

\subsubsection{KT07-Series Glasses}

The KT07-series glasses were designed to evaluate any potential impacts of noble metals on the properties and performance of the glasses. The glasses characterized in the previous KT-series studies did not include noble metals since they are not typically tracked in sludge batch composition projections. However, noble metals can act as nucleation sites in glass melts, leading to enhanced crystallization. This crystallization can potentially influence the properties and performance of the glass, such as chemical durability, viscosity, and liquidus temperature. A set of glass compositions developed earlier in the SCIX study, the KT04-series, was used as the basis for the KT07-series glasses. The noble metals Ag, Pd, Rh, and Ru were added. The 
concentrations of these metals were obtained from measurements of Sludge Batch 6, which was considered to contain a high concentration of noble metals. ${ }^{15}$

After fabrication, the glasses were characterized to determine their crystalline content, chemical composition, durability, and viscosity. Liquidus temperature estimates were also completed, as described in Section 3.0. All of the KT07-series glasses, both quenched and CCC, were found to be amorphous by XRD. Chemical composition measurements showed that all of the glasses met the targeted compositions. The PCT results showed that all of the glasses, both quenched and CCC, had chemical durabilities that were far better than that of the EA benchmark glass. The measured PCT responses were well predicted by the current DWPF PCCS durability models. The measured viscosity values for each KT07-series glass were acceptable for DWPF processing and were well predicted by the current PCCS model.

Overall, the results indicate that the inclusion of relatively high concentrations of noble metals (in terms of expected values for a DWPF sludge batch) had no significant impact on the properties and performance of these glass compositions other than the liquidus temperature estimates. The lack of crystallization in the KT07-series glasses after fabrication and after the CCC, their measured PCT responses, and their measured viscosity values are very consistent with the KT04series glasses, which did not contain noble metals. As discussed in Section 3.0, the noble metals led to faster crystallization at a given temperature. The trend of the model predicted $T_{L}$ values being lower than the measured ranges for high $\mathrm{TiO}_{2}$ concentration glasses continued.

\subsubsection{KT08 through KT10-Series Glasses:}

The KT08-series of glasses was designed to evaluate any impacts of the inclusion of uranium and thorium in high $\mathrm{TiO}_{2}$ concentration glasses. The KT09-series of glasses was designed to study the effect of increasing $\mathrm{Al}_{2} \mathrm{O}_{3}$ and $\mathrm{K}_{2} \mathrm{O}$ concentrations on the propensity for crystallization of titanium containing phases, based on recommendations from the KT05 study. The KT10-series of compositions was designed to evaluate any impacts of the SCIX components at concentrations significantly higher than currently projected. The glasses were fabricated in the laboratory and characterized using XRD to identify crystallization, ICP-AES to verify chemical compositions, and the PCT to measure durability. The viscosity and liquidus temperature of several of the glasses were also measured.

All but one of the KT08-series glasses were found to be amorphous by XRD. One of the CCC glasses contained a small amount of trevorite, which had no practical impact on the durability of the glass. The measured PCT responses of the KT08-series glasses were well predicted by the DWPF models, and the viscosities of the KT08-series glasses were generally well predicted by the DWPF model.

The KT09-series glasses were fabricated, subjected to the CCC heat treatment, and characterized via XRD only, since the type of crystallization formed, if any, was the characteristic of interest for these compositions. Increased $\mathrm{Al}_{2} \mathrm{O}_{3}$ concentrations were not successful in preventing the formation of iron titanate crystals in the KT09-series glasses. Increased $\mathrm{K}_{2} \mathrm{O}$ concentrations were successful in hindering the formation of iron titanates in some of the glasses after the CCC heat treatment. However, this result did not apply to all of the CCC versions of the glasses, indicating a compositional dependence of this effect. In addition, high concentrations of $\mathrm{K}_{2} \mathrm{O}$ have been shown to be detrimental to some glass properties other than crystallization (see the results for the KT01 and KT03 series in Section 4.2.1). The usefulness of increased $\mathrm{K}_{2} \mathrm{O}$ concentrations in preventing the formation of iron titanates may therefore be limited. 
All of the KT10-series glasses were XRD amorphous, regardless of whether they were quenched or subjected to the CCC heat treatment. Chemical composition measurements showed that the glasses met the targeted concentrations for each oxide. In general, the measured PCT responses of the KT10-series glasses were well predicted by the DWPF models. The measured, normalized release values for silicon for some of the glasses fell above the $95 \%$ confidence interval for the predicted values; however, the PCT responses for these glasses remain considerably lower than that of the benchmark EA glass. The viscosities of the KT10-series glasses were generally well predicted by the DWPF model. Liquidus temperature estimates for the KT10-series glasses were discussed earlier in Section 3.0.

\subsection{Recommendations and Path Forward}

This report summarizes a large amount of experimental work completed to identify the potential impacts of material from SCIX on glass formulation at the DWPF. The results indicate no significant issues with the predicted values of chemical durability and viscosity using the current PCCS models when the SCIX components are added to projected DWPF glass compositions. No modifications to the viscosity and durability models appear to be necessary at this time in order to incorporate the SCIX streams at DWPF. It is recommended that SRNL continue to verify the durability and viscosity models as the projected compositions for DWPF processing evolve. It is also recommended that the data generated thus far be reviewed and a determination be made as to how best to extend the validation ranges of the durability and viscosity models.

The liquidus temperatures for the experimental glasses were also reported and discussed in this report. The results show that the measured or estimated (based on measured data) liquidus temperature values for the glasses with SCIX components added are consistently higher than those predicted by the current model. Therefore, the PCCS liquidus temperature model will need to be modified in order to incorporate the SCIX streams at DWPF. It is recommended that SRNL carry out full measurements of the liquidus temperatures for those KT-series glasses where estimates have been made. These data should then be used to support an evaluation of whether a refitting of the liquidus temperature model coefficients will be sufficient to correctly predict the liquidus temperature of glasses containing the SCIX components (particularly higher $\mathrm{TiO}_{2}$ concentrations), or whether additional modifications to the model are required. All further liquidus temperature experiments should include noble metals in the glass, and longer heat treatment periods should be considered.

While there are prediction issues with the current liquidus temperature model, they are not at this time expected to hamper the incorporation of SCIX streams at DWPF. The estimated liquidus temperatures, while higher than the model predicted values, remain below the current DWPF limit of $1050{ }^{\circ} \mathrm{C}$ for most of the study glasses. Note that the properties and performance of the glasses in this study are highly dependent on glass composition. Therefore, should significant changes be made to the projected compositions or processing rates for SCIX or DWPF, many of the assessments and experiments may have to be revisited.

\subsection{References}

1. Fellinger, T. L., "Technical Task Request: DWPF Glass Evaluation for the Introduction of MSP Products into Future Sludge Batches," U.S. Department of Energy Report HLW-DWPFTTR-2010-0009, Revision A, Savannah River Remediation, Aiken, SC (2010).

2. Fox, K. M., "Task Technical and Quality Assurance Plan for Evaluation of the Introduction of Modular Salt Processing Products to Defense Waste Processing Facility Glass for Future Sludge 
Batches,” U.S. Department of Energy Report SRNL-RP-2010-00560, Revision 0, Savannah River National Laboratory, Aiken, SC (2010).

3. Edwards, T. B., K. G. Brown and R. L. Postles, "SME Acceptability Determination for DWPF Process Control," U.S. Department of Energy Report WSRC-TR-95-00364, Revision 5, Washington Savannah River Company, Aiken, SC (2006).

4. Fox, K. M. and T. B. Edwards, "Impacts of Small Column Ion Exchange Streams on DWPF Glass Formulation: KT01, KT02, KT03, and KT04-Series Glass Compositions,” U.S. Department of Energy Report SRNL-STI-2010-00566, Revision 0, Savannah River National Laboratory, Aiken, SC (2010).

5. “Isothermal Liquidus Temperature Measurement Procedure," Manual L29, ITS-0025, Savannah River National Laboratory, Aiken, SC (2009).

6. “Furnace Functional Check,” Manual L29, ITS-0096, Savannah River National Laboratory, Aiken, SC (2009).

7. “Microscopy Sample Preparation,” Manual L29, ITS-0017, Savannah River National Laboratory, Aiken, SC (2008).

8. Brown, K. G., C. M. Jantzen and G. Ritzhaupt, "Relating Liquidus Temperature to Composition for Defense Waste Processing Facility (DWPF) Process Control," U.S. Department of Energy Report WSRC-TR-2001-00520, Revision 0, Westinghouse Savannah River Company, Aiken, SC (2001).

9. Fox, K. M. and T. B. Edwards, "Impacts of Small Column Ion Exchange Streams on DWPF Glass Formulation: KT07-Series Glass Compositions," U.S. Department of Energy Report SRNLSTI-2010-00759, Revision 0, Savannah River National Laboratory, Aiken, SC (2010).

10. Fox, K. M., T. B. Edwards, M. E. Stone and D. C. Koopman, "Paper Study Evaluations of the Introduction of Small Column Ion Exchange (SCIX) Waste Streams to the Defense Waste Processing Facility,” U.S. Department of Energy Report SRNL-STI-2010-00297, Revision 0, Savannah River National Laboratory, Aiken, SC (2010).

11. Peeler, D. K. and T. B. Edwards, "High-Level Review of the Impacts of CST and RF on DWPF Processing: A Glass Formulation Perspective,” U.S. Department of Energy Memorandum SRNL-PSE-2007-00177, Washington Savannah River Company, Aiken, SC (2007).

12. Fox, K. M. and T. B. Edwards, "Impacts of Small Column Ion Exchange Streams on DWPF Glass Formulation: KT05 and KT06-Series Glass Compositions,” U.S. Department of Energy Report SRNL-STI-2010-00687, Revision 0, Savannah River National Laboratory, Aiken, SC (2010).

13. Fox, K. M. and T. B. Edwards, "Impacts of Small Column Ion Exchange Streams on DWPF Glass Formulation: KT08, KT09, and KT10-Series Glass Compositions," U.S. Department of Energy Report SRNL-STI-2011-00178, Revision 0, Savannah River National Laboratory, Aiken, SC (2011). 
14. Jantzen, C. M., "The Impacts of Uranium and Thorium on the Defense Waste Processing Facility (DWPF) Viscosity Model,” U.S. Department of Energy Report WSRC-TR-2004-00311, Revision 0, Westinghouse Savannah River Company, Aiken, SC (2005).

15. Lambert, D. P. and A. S. Choi, "DWPF Coal-Carbon Waste Acceptance Criteria Limit Evaluation Based on Experimental Work (Tank 48 Impact Study)," U.S. Department of Energy Report SRNL-STI-2010-00589, Revision 0, Savannah River National Laboratory, Aiken, SC (2010). 
SRNL-STI-2011-00198

Revision 0

Appendix A. Measured and Estimated $\mathrm{T}_{\mathrm{L}}$ Data for the KT-Series Glasses. 
Table A-1. Model Predicted and Measured Liquidus Temperatures for the KT01-Series Glasses.

\begin{tabular}{|l|c|c|c|c|c|}
\hline Glass ID & $\begin{array}{c}\text { Model Predicted } \\
\mathbf{T}_{\mathbf{L}}\left({ }^{(} \mathbf{C}\right)\end{array}$ & $\begin{array}{c}\text { Model Prediction } \\
\text { Lower Limit }\left({ }^{\circ} \mathbf{C}\right)\end{array}$ & $\begin{array}{c}\text { Model Prediction } \\
\text { Upper Limit }\left({ }^{\circ} \mathbf{C}\right)\end{array}$ & $\begin{array}{c}\text { Measured } \mathbf{T}_{\mathbf{L}} \\
\left({ }^{\circ} \mathbf{C}\right)\end{array}$ & Predictable? \\
\hline KT01-HB & 881 & 820 & 948 & $923+/-5$ & Yes \\
\hline KT01-HF & 934 & 868 & 1008 & $1056+/-5$ & No \\
\hline KT01-HL & 854 & 797 & 918 & $942+/-10$ & No \\
\hline KT01-HN & 860 & 801 & 925 & $915+/-10$ & Yes \\
\hline KT01-HS & 877 & 817 & 945 & $923+/-5$ & Yes \\
\hline KT01-LA & 847 & 789 & 911 & $913+/-5$ & No \\
\hline KT01-LB & 878 & 818 & 945 & $933+/-5$ & Yes \\
\hline KT01-LF & 833 & 778 & 895 & $908+/-5$ & No \\
\hline KT01-LL & 882 & 822 & 949 & $943+/-5$ & Yes \\
\hline KT01-LN & 909 & 846 & 980 & $965+/-5$ & Yes \\
\hline KT01-LS & 877 & 817 & 944 & $937+/-5$ & Yes \\
\hline
\end{tabular}


Table A-2. Model Predicted and Estimated Liquidus Temperature Data for Several of the KT-Series Glasses.

\begin{tabular}{|c|c|c|c|c|}
\hline Glass ID & $\begin{array}{c}\text { Model Predicted } \\
T_{L}\left({ }^{\circ} \mathrm{C}\right) \\
\end{array}$ & $\begin{array}{l}\text { Model Prediction } \\
\text { Lower Limit }\left({ }^{\circ} \mathrm{C}\right) \\
\end{array}$ & $\begin{array}{l}\text { Model Prediction } \\
\text { Upper Limit }\left({ }^{\circ} \mathrm{C}\right) \\
\end{array}$ & $\begin{array}{c}\text { Estimated } T_{L} \\
\left({ }^{\circ} \mathrm{C}\right)\end{array}$ \\
\hline KT03-HA & 944 & 877 & 1020 & $947-1024$ \\
\hline KT03-HB & 903 & 840 & 973 & $916-965$ \\
\hline KT03-HF & 965 & 895 & 1043 & $968-1047$ \\
\hline KT03-HL & 865 & 807 & 930 & $920-939$ \\
\hline KT03-HN & 871 & 812 & 938 & $876-940$ \\
\hline KT03-HS & 893 & 831 & 962 & $897-963$ \\
\hline KT03-LA & 884 & 823 & 951 & $897-946$ \\
\hline KT03-LB & 904 & 842 & 974 & $916-962$ \\
\hline KT03-LF & 856 & 799 & 921 & $856-920$ \\
\hline KT03-LL & 901 & 839 & 971 & $914-966$ \\
\hline KT03-LN & 914 & 850 & 985 & $914-989$ \\
\hline KT03-LS & 901 & 839 & 971 & $916-965$ \\
\hline KT04-01 & 912 & 851 & 981 & $929-976$ \\
\hline KT04-02 & 873 & 814 & 938 & $899-930$ \\
\hline KT04-03 & 859 & 802 & 923 & $874-934$ \\
\hline KT04-04 & 870 & 811 & 936 & $881-930$ \\
\hline KT04-05 & 886 & 825 & 954 & $901-946$ \\
\hline KT04-06 & 861 & 803 & 926 & $900-921$ \\
\hline KT04-07 & 870 & 811 & 936 & $900-966$ \\
\hline KT04-08 & 841 & 784 & 904 & $856.5-901$ \\
\hline KT04-09 & 886 & 824 & 955 & $914-975$ \\
\hline KT04-10 & 913 & 848 & 986 & $929-985$ \\
\hline KT06-01 & 888 & 828 & 955 & $913-945$ \\
\hline KT06-02 & 921 & 856 & 993 & $943-991$ \\
\hline KT06-03 & 877 & 818 & 943 & $914-930$ \\
\hline KT06-04 & 927 & 862 & 999 & $>998$ \\
\hline KT06-05 & 955 & 887 & 1031 & $965-1026$ \\
\hline KT06-06 & 953 & 885 & 1028 & $963-1026$ \\
\hline KT06-07 & 947 & 883 & 1019 & $964-1017$ \\
\hline
\end{tabular}


Table A-2. Model Predicted and Estimated Liquidus Temperature Data for Several of the KT-Series Glasses. (continued)

\begin{tabular}{|c|c|c|c|c|}
\hline Glass ID & $\begin{array}{c}\text { Model Predicted } \\
\mathbf{T}_{\mathrm{L}}\left({ }^{\circ} \mathrm{C}\right) \\
\end{array}$ & $\begin{array}{l}\text { Model Prediction } \\
\text { Lower Limit }\left({ }^{\circ} \mathrm{C}\right)\end{array}$ & $\begin{array}{l}\text { Model Prediction } \\
\text { Upper Limit }\left({ }^{\circ} \mathrm{C}\right)\end{array}$ & $\begin{array}{c}\text { Estimated } T_{L} \\
\left({ }^{\circ} \mathrm{C}\right)\end{array}$ \\
\hline KT06-08 & 935 & 870 & 1008 & $965-1006$ \\
\hline KT06-09 & 916 & 853 & 987 & $942.5-976$ \\
\hline KT06-10 & 918 & 857 & 987 & $944.5-976$ \\
\hline KT06-11 & 981 & 910 & 1061 & $991-1050$ \\
\hline KT06-12 & 975 & 905 & 1054 & $<995$ \\
\hline KT06-13 & 932 & 869 & 1002 & $>996$ \\
\hline KT06-14 & 934 & 866 & 1011 & $966-1005$ \\
\hline KT06-15 & 946 & 880 & 1020 & $964-1016$ \\
\hline KT06-16 & 903 & 843 & 970 & $>965$ \\
\hline KT06-17 & 927 & 861 & 1002 & $940-990$ \\
\hline KT06-18 & 967 & 898 & 1044 & $992-1041$ \\
\hline KT07-01 & 925 & 863 & 996 & $>1000$ \\
\hline KT07-02 & 880 & 821 & 946 & $944-1035$ \\
\hline KT07-03 & 886 & 827 & 952 & $948-1031$ \\
\hline KT07-04 & 883 & 823 & 951 & $950-1034$ \\
\hline KT07-05 & 889 & 828 & 957 & $>951$ \\
\hline KT07-06 & 893 & 831 & 961 & $953-1034$ \\
\hline KT07-07 & 898 & 836 & 967 & $965-1031$ \\
\hline KT07-08 & 861 & 803 & 926 & $924-987$ \\
\hline KT07-09 & 910 & 846 & 982 & $>980$ \\
\hline KT07-10 & 926 & 860 & 1001 & $>999$ \\
\hline KT10-01 & 912 & 850 & 981 & $>971$ \\
\hline KT10-02 & 870 & 812 & 935 & $>934$ \\
\hline KT10-03 & 863 & 806 & 927 & $>920$ \\
\hline KT10-04 & 873 & 814 & 939 & $>932$ \\
\hline KT10-05 & 880 & 820 & 947 & $>942$ \\
\hline KT10-06 & 878 & 819 & 944 & $>944$ \\
\hline KT10-07 & 882 & 822 & 950 & $>942$ \\
\hline KT10-08 & 843 & 786 & 906 & $>902$ \\
\hline KT10-09 & 894 & 831 & 963 & $>957$ \\
\hline KT10-10 & 911 & 847 & 983 & $>973$ \\
\hline
\end{tabular}




\section{Distribution:}

J. W. Amoroso, 999-W

A. B. Barnes, 999-W

A. L. Billings, 999-W

J. M. Bricker, 704-27S

M. A. Broome, 704-29S

C. L. Crawford, 773-42A

D. A. Crowley, 773-43A

R. E. Edwards, 773-67A

T. B. Edwards, 999-W

T. L. Fellinger, 704-26S

S. D. Fink, 773-A

K. M. Fox, 999-W

B. J. Giddings, 786-5A

J. M. Gillam, 766-H

B. A. Hamm, 766-H

C. C. Herman, 999-W

D. T. Herman, 735-11A

R. N. Hinds, 704-S

E. W. Holtzscheiter, 704-15S

T. H. Huff, 773-66A
J. F. Iaukea, 704-30S

P. R. Jackson, 703-46A

C. M. Jantzen, 773-A

F. C. Johnson, 999-W

D. C. Koopman, 999-W

P. L. Lee, 703-41A

S. L. Marra, 773-A

D. W. Mcilmoyle, 766-H

D. H. Miller, 999-W

J. E. Occhipinti, 704-S

D. K. Peeler, 999-W

F. M. Pennebaker, 773-42A

J. W. Ray, 704-S

M. A. Rios-Armstrong, 773-66A

H. B. Shah, 766-H

D. C. Sherburne, 704-S

A. V. Staub, 704-27S

M. E. Stone, 999-W

K. H. Subramanian, 766-H

J. P. Vaughan, 773-41A 